\title{
RASIONALITAS KEBIJAKAN PEMEKARAN KECAMATAN DAN KELURAHAN DI KOTA BANDAR LAMPUNG
}

\section{RATIONALITY DISTRICT POLICY PROLIFERATION AND VILLAGES IN TOWN BANDAR LAMPUNG}

\author{
Novita Tresiana \\ Fakultas Ilmu Sosial dan Ilmu Politik, Universitas Lampung \\ Jl. Prof. Dr. Sumantri Brodjonegoro Nomor 1 Bandar Lampung, 35145 \\ HP. 081279093299 \\ Email: novitatresiana@yahoo.co.id \\ Dikirim: 9 Januari 2015 Direvisi: 23 Maret 2015 Disetujui: 20 April 2015
}

\begin{abstract}
Abstrak
Penelitian ini didasari pemikiran bahwa pemekaran wilayah merupakan sebuah produk kebijakan publik, sebagai upaya pemerintah untuk memecahkan masalah publik. Dalam kerangka rasionalitas, maka kebijakan pemekaran seharusnya adalah hasil pilihan yang rasional, mencakup pemilihan alternative bagi tercapainya tujuan, mengandung nilai yang fundamental dan tepat guna untuk mencapai hasil akhir (outcome) yang diinginkan. Tujuan dari penulisan ini adalah : mendeskripsikan proses pembuatan kebijakan pemekaran dan mendeskripsikan rasionalitas yang digunakan aktor dalam kebijakan pemekaran. Metode yang digunakan adalah kualitatif. Tulisan ini mengangkat temuan hasil penelitian bahwasanya proses penetapan kebijakan pemekaran, bukanlah upaya solutif bagi persoalaan substantive masyarakat dan rasionalitas yang digunakan dalam penetapan kebijakan, didominasi model rasionalitas tong sampah, sebagai respon struktur terhadap kepentingannya elit (politik), bersifat transaksional, bukanlah respon sistem (legislatif dan eksekutif) untuk mengatasi masalah faktual yang berkaitan dengan kesejahteraan masyarakat.

Kata Kunci : Rasionalitas, Perumusan Kebijakan
\end{abstract}

\section{Abstract}

This study is based on the premise that regional growth is a product of public policy, as the government attempts to solve public problems. Within the framework of rationality, then the expansion policy should be the result of rational choice, including the selection of alternatives for the achievement of objectives, contain a fundamental value and appropriate to achieve the end result (outcome) is desired. The purpose of this paper is: to describe the process of policy-making division and rationality that are used to describe the actors in the division policy. The method used is qualitative. This paper raised the research findings that the process of defining the division policy, not the effort solutif the problem for substantive society and rationality that are used in the determination of policy, dominated model of rationality dustbin, as a structural response to the interests of elite (political), transactional, not a system response (legislative and executive) to address the factual issues relating to the welfare of society.

Keywords: Rationality; Policy Formulation

\section{PENDAHULUAN}

Implementasi kebijakan otonomi daerah yang lalu, sebagai mana tertuang dalam Undang-Undang Nomor 32 Tahun 2004, telah membawa perubahan baru dibanding undang-undang sebelumnya. Muncul euphoria kebebasan dan demokrasi dalam pengaturan kehidupan masyarakat daerah. Substansi penting dari semangat kebijakan di atas adalah penyerahan kewenangan dari pemerintah pusat kepada masyarakat sebagai pilar utama pemerintah daerah. Sayangnya, semangat dan euphoria demokrasi disikapi pemerintah daerah yang hanya berhenti di titik politik, salah satunya pemekaran daerah-daerah baru, yang pada akhirnya membebankan anggaran pendapatan dan belanja daerah, untuk urusan membiayai para elite politik daerah baru ketimbang untuk mengentaskan kemiskinan dan pengangguran. Weick and Quinn (1999), berpendapat kebijakan pemekaran sebagai wujud restrukrisasi merupakan "focus on changing rather than change". Artinya restrukturisasi oleh agen perubahan (kepala daerah) lebih fokus pada kegiatan merubah ketimbang pada dampak (hasil) perubahan sesuai kehendak masyarakat daerah. Dengan kata lain pemekaran lebih berkutat pada cara, bukan tujuan (hasil) yang berdampak positif bagi masyarakat di daerah. Pandangan ahli di atas, diperkuat adanya hasil evaluasi yang dilakukan Kementrian Dalam Negri berkaitan dengan pemekaran daerah dan wilayah administratif di tahun 2010 bahwasanya: Pertama, dalam kurun waktu 10 tahun sejak tahun 
1999 telah terbentuk daerah otonom baru sebanyak 205 buah yang terdiri dari 7 provinsi, 164 kabupaten dan 34 Kota. Hal ini menunjukan terjadi peningkatan $64 \%$ dari jumlah daerah otonom tahun 1998 atau secara rata rata dalam satu tahun lahir 20 daerah otonom baru. Kedua, banyaknya daerah otonom baru tersebut memiliki implikasi terhadap semakin besarnya dana pembangunan daerah otonom baru yang dialokasikan dari APBN. Pada tahun 2002 dialokasikan DAU sebesar Rp. 1.33 triliun, tahun 2003 sebesar Rp. 2.6 triliun dan pada tahun 2010 sebesar Rp. 47.9 triliun (dalam situs www.kemendagri.com).

Penelitian tentang pemekaran wilayah di Kota Bandar Lampung, dilatari oleh pemikiran bahwasanya dalam kerangka substantif, pemekaran wilayah baik kecamatan maupun kelurahan adalah sebuah produk kebijakan publik, yang haruslah berada pada ranah upaya pemerintah untuk memecahkan masalah publik di wilayah bersangkutan, karenanya haruslah diupayakan berada dalam rel kebijakan yang beraras pada sebesarbesarnya kepentingan publik.

Dunn (2000: 207) menggambarkan analisis lahirnya kebijakan pemekaran wilayah, memiliki komponen-komponen sebagai berikut: pertama, bagaimana merumuskan masalah-masalah kebijakan, dimana masing-masing tahap perumusan masalah memerlukan ketrampilan, yang berhubungan dengan rasionalitas. Rasionalitas tidak semata-mata berupa penemuan penggambaran formal yang memadai atas masalah melalui prosedur-prosedur tehnis, misalnya melalui model matematika. Namun yang lebih penting, berkenaan dengan penemuan penggambaran konseptual yang memadai atas masalah, yang membutuhkan adanya kesadaran diri dan pemilihan yang kritis atas pandangan-pandangan. Kedua, merumuskan kebijakan sebagai strategi dan tools pemecahan masalah, dimana akan menghasilkan informasi tentang kemungkinan serangkaian aksi dimasa datang untuk menghasilkan konsekuensi yang berharga bagi individu, kelompok dan masyarakat seluruhnya. Prosedur perumusan kebijakan meliputi, transformasi informasi mengenai kebijakan (program) dimasa depan kedalam informasi mengenai aksi-aksi kebijakan yang akan menghasilkan keluaran yang bernilai.

Subarsono (2005:65) berpendapat bahwa rumusan kebijakan merupakan pemberian alternatif kebijakan yang paling unggul dibanding alternatif kebijakan yang lain. Karenanya proses pemilihan alternatif harus berdasar pada seperangkat kriteria yang jelas dan transparan, sehingga ada argumentasi suatu alternatif kebijakan dipilih atau ditolak. Dalam konteks ini aspek rasionalitas dari sebuah alternatif merupakan pertimbangan utama dalam memilih alternatif kebijakan/program.

Lindblom (1986:2), melalui penelitiannya menyatakan, bahwa dalam konteks alam demokratis, maka ada dua hal mendasar yang berkaitan dengan kebijakan publik yang ideal di suatu negara, yaitu: pertama, kemampuan/keampuhan kebijakan dalam memecahkan masalah publik. Kedua, kepekaannya terhadap kontrol sosial. Pertanyaan pertama mengambil bentuk apakah perumus kebijakan memiliki pemahaman (pengetahuan), kehendak/wewenang dalam menangani masalahmasalah publik yang cukup luas dan rumit. Sementara yang terakhir tampil dalam bentuk siapasiapa saja yang terlibat dalam merumuskan kebijakan publik. Duadji (2013) memperkuat pernyataan Linblom, tentag perlunya partisipasi masyarakat dalam pengambilan keputusan di daerah. Senada dengan pendapat diatas, penelitian Long \& Long ( 1992) memperjelas dalam penyimpulannya, bahwa kebijakan publik dalam konteks perumusan, haruslah partisipatif, interaksi aktor harus berlangsung secara setara, intersif dan interface. Sementara De Zeeuw (dalam Prasetyo,2012), dalam sebuah penelitiannya menyimpulkan bahwa dalam perumusan kebijakan publik haruslah memperhatikan potensi dan kemampuan masyarakat anggota kolektivitas secara keseluruhan sehingga kebijakan yang ditentukan tidak memihak dan dapat diakses oleh seluruh aktor yang terlibat dalam kolektivitas tersebut, bukan kehendak orang per orang. Terhadap berbagai penelitian di atas, maka Duadji (2012) melalui penelitiannya, menggambarkan konteks kebijakan public yang ideal dilakukan dengan pemenuhan 3 pilar dari governance, yakni akuntabilitas, transparansi dan partisipasi. Ketiga hal harus terimplementasi dalam perumusan kebijakan melalui landasan legal formal.

Berkaitan khusus dengan kebijakan pemekaran, penelitian yang dilakukan oleh Fitri (2012), menggambarkan bahwa faktor lingkungan sebagai dimensi penting dalam kebijakan public, diabaikan dalam proses perumusan kebijakan, proses perumusan jauh dari nilai-nilai demokratis, dan lebih mengedepankan nilai politik ketimbang nilai ekonomi, social dan nilai-nilai lainnya.

Secara makro, kerangka teori yang digunakan untuk memahami kebijakan pemekaran wilayah adalah teori rasionalitas. Bangunan teori rasionalitas sebagaimana dikemukakan oleh Simon (dalam Parson 2006:274), diawali dengan mendifiniskan kebijakan sebagai sebuah pemilihan alternative dari sejumlah alternative yang ada, sehingga pilihan yang rasional (rational choice) mencakup pemilihan alternative bagi tercapainya tujuan dan nilai yang fundamental dan tepat guna untuk mencapai hasil akhir (outcome) yang diinginkan. Ada beberapa hal penting yag menjadi perhatian dari penggunaan teori ini, yaitu: pertama, nilai dan tujuan siapa yang harus diperhatikan dalam pembuatan kebijakan. Kedua, kebijakan bisa saja tidak menyinggung sama sekali tujuan yang akan dicapai oleh sebuah organisasi. Ketiga, dalam praktek sulit ditemui aktor mempertimbangkan semua alternative yang tersedia (Wahab,2008: 99). Atas dasar hal di atas, maka Cyert 
dan March dalam Frederickson (2012:68) mengemukakan sebuah model rasionalitas tong sampah dalam pembuatan kebijakan dimana kondisinya beberapa isu akan punya solusi, sedangkan yang lainnya tidak, dan ada solusi lainnya yang barangkali sedang mencari isu-isu yang akan mereka selesaikan. Pengambil kebijakan mungkin akan membuang semua problem/solusi dalam tong apapun yang tersedia atau kedalam tong-tong yang kosong dan cukup untuk menampung solusi atau problem itu. Model ini menunjukkan bahwa isu, problem, dan solusi berada dalam kondisi campur baur, tidak rapi. Pembuatan akan mengidentifikasikan berdasarkan saat ia diambil dan ketersediaan tong untuk menempatkannya. Model tong sampah dideduksi dari asumsi bahwa nilai-nilai adalah kompleks, pengetahuan adalah tidak pasti, aturan adalah kompleks, pembuatan kebijakan hanya melibatkan tindakan simbolik.

Kota Bandar Lampung sebelum era reformasi terdiri dari 9 kecamatan dan 84 kelurahan; tetapi sejak tahun 2001 bertambah menjadi 13 kecamatan dan 98 kelurahan; dan hingga tahun 2012 yang lalu ditambah 7 kecamatan dan 28 kelurahan, sehingga total memiliki 20 kecamatan dan 126 kelurahan (Tresiana,2013). Pemilihan pemekaran pada kecamatan dan kelurahan kota di Bandar Lampung sebagai obyek kajian didasari pertimbangan: 1) berdasakan kebijakan tentang pemerintah daerah sebagaimana tertuang dalam Undang-Undang Nomor 32 Tahun 2004 yang menjadi rujukan pada waktu itu, sebuah kecamatan/kelurahan baru dan kelurahan baru dapat dibentuk secara langsung, dengan peraturan daerahnya masing-masing; 2) Pembentukan kecamatan/keluran baru marak dilakukan menjelang hajat politik daerah; 3) pembentukan kecamatan/kelurahan baru seringkali didasari oleh pertimbangan politis untuk bahan pembentukan kabupaten/kota baru yang kontraproduktif dengan peningkatan, pemerataan pembangunan serta pelayanan umum, yang seharusnya menjadi alasan utama; 4) dalam perspektif rasionalitas, maka nilai dan tujuan dari aktor-aktor pembuat kebijakan akan cukup menentukan pilihan atas kebijakan yang diambil untuk menyelesaikan persoalan kepublikan. Latar keempat inilah yang akan mewarnai bahasan dalam tulisan ini.

Dari latar pemikiran tersebut ditarik permasalahan penelitian sebagai berikut: "rasionalitas apakah yang menjadi pijakan aktor kebijakan di Kota Bandar Lampung dalam menetapkan kebijakan pemekaran kecamatan dan kelurahan?”. Tujuan penelitian ini adalah: 1) Mendeskripsikan proses pembuatan dan penetapan kebijakan pemekaran kecamatan/kelurahan di Kota Bandar Lampung; 2) Mendeskripsikan rasionalitas yang digunakan aktor dalam kebijakan pemekaran kecamatan/kelurahan di Kota Bandar Lampung.

\section{METODE}

Desain penelitian ini diarahkan untuk menjelaskan obyek penelitian yang berkenaan dengan upaya untuk menggambarkan persoalan, proses dan preferensi rasionalitas kebijakan pemekaran kecamatan dan kelurahan di Kota Bandar Lampung. Untuk itu, metode kualitatif dipilih. Jenis data meliputi: (a) data primer bersumber dari observasi lapang dan wawancara kepada informan; dan (b) data sekunder bersumber dari dokumen penting berupa dokumen kebijakan pemekaran kelurahan; laporan dan catatan-catatan studi kelayakan yang dilakukan tim ekspatriat (think tank, konsultan, tenaga ahli); notulensi sidang dan agenda rapat DPRD Kota Bandar Lampung yang ada di Sekretariat Dewan, dan informasi lain dari buku dan media lokal/nasional lainnya.

Keabsahan data merupakan standar validitas data yang diperoleh. Uji kredibilitas (validitas) menggunakan metode triangulasi sumber, data dan informasi dengan melakukan recheck dan crosscheck (Creswell,2002:147). Sedangkan Informan penelitian adalah subyek yang terlibat langsung, atau setidaktidaknya mengetahui, memiliki informasi dan kompetensi terkait kebijakan pemekaran kecamatan dan kelurahan dengan dorongan kesadaran, keikhlasan, kejujuran, mau bekerjasama dan membantu peneliti. Adapun informan penelitian ini terdiri dari: Sekretaris dan staf sekretariat DPRD Kota Bandar Lampung; Kepala Sub Bagian Tata Pemerintahan Umum dan Kepala Sub Bagian Hukum Sekretariat Daerah Kota Bandar Lampung; 2 orang anggota DPRD Komisi A Kota Bandar Lampung; 2 orang akademisi Universitas Lampung sebagai think tank; 10 orang lurah; 3 orang tokoh masyarakat/aktivis dan penggiat LSM; dan 15 orang masyarakat.

Analisis data melingkupi beberapa tahapan kegiatan, yaitu: (1) penentuan jenis dan sumber data yang diperlukan; (2) pengumpulan data melalui observasi, wawancara dan dokumentasi; (3) penyajian, pemaparan dan interpretasi data lapang dengan melakukan pengkategorian makna emik dan mendapatkan makna etik melalui komparasi dengan konsep dan sandaran teori; dan (4) merumuskan konsep sebagai temuan. Terkait dengan konteks dan aspek geografis, lokasi penelitian ini dilakukan di Kota Bandar Lampung. Sementara dalam makna situs ada 3 hal yang menjadi perhatian. Pertama, tempat kejadian yang berkaitan dengan proses perumusan kebijakan pemekaran kelurahan. Kedua, terkait dengan konteks dan isi kebijakan pemekaran wilayah kecamatan dan kelurahan. Ketiga, wilayah kecamatan dan kelurahan induk serta hasil pemekaran. 


\section{HASIL DAN PEMBAHASAN}

\section{Deskripsi Proses Perumusan Kebijakan Pemekaran Kecamatan/Kelurahan di Kota Bandar Lampung}

Kebijakan pemekaran kecamatan dan kelurahan di Kota Bandar Lampung hakikinya diharapkan dapat meningkatkan pelayanan publik guna mempercepat terwujudnya kesejahteraan masyarakat. Untuk itu perlu diperhatikan dan dipertimbangkan berbagai faktor, mulai dari potensi dan kondisi geografis, demografis, kemampuan ekonomi, social politik, social budaya, pertahanan keamanan serta pertimbangan dan syarat lain yang diatur dalam ketentuan yang berlaku (Safarudin, 2009).Untuk ketercapaian hal di atas, maka proses identifikasi apa yang menjadi masalah riil masyarakat dan proses perumusan kebijakan untuk menyelesaikan masalah riil masyarakat, menjadi dimensi yag menentukan ketercapaian hasil (outcome) kebijakan pemekaran kecamatan/kelurahan.

Keterkaitan dengan masalah/kebutuhan masyarakat Kota Bandar Lampung, dikemukakan dalam penelitian yang dilakukan Tresiana (2013), yaitu: pertama, masih tingginya angka kemiskinan. Tercatat jumlah penduduk miskin di kota ini adalah 276.474 jiwa $(31,4 \%)$ dari total jumlah penduduk 879.651 jiwa. Kedua, buruknya kualitas layanan publik dan masih rendahnya kinerja aparatur daerah yang diindikasikan oleh masih tingginya angka korupsi dalam penyelenggaraan layanan publik. Laporan hasil survey dan kajian Komisi Pemberantasan Korupsi (KPK) memperkuat hal di atas, sebagaimana tampak pada Tabel 1 dan Tabel 2.

Atas dua masalah utama yang dihadapi masyarakat Kota Bandar Lampung, maka pemerintah memandang bahwa tindakan (kebijakan) pemekaran wilayah kecamatan/kelurahan adalah merupakan sesuatu yang urgen dan perlu diprioritaskan.

Ada 5 hal yang melatarbelakangi pentingnya Kota Bandar Lampung melakukan pemekaran kelurahan dan kecamatan: Pertama, masyarakat Kota Bandar Lampung membutuhkan pelayanan publik yang memadai, cepat dan dekat dari aparatur pemerintah kota, baik yang berkenaan layanan administratif, jasa, dan ketersediaan sarana serta fasilitas umum. Disinyalir bahwa pelayanan publik belum memadai dan penyebabnya adalah keterbatasan jumlah kelembagaan dan personel aparatur pemerintah kota yang dimaknai sebagai hambatan rentang kendali pelayanan; Kedua, tidak meratanya sebaran penduduk baik pada tingkat kecamatan maupun pada tingkatan kelurahan di Kota Bandar Lampung yang membutuhkan pengaturan secara proporsional; Ketiga, rendahnya partisipasi masyarakat dan disinyalir penyebabnya adalah belum tergalinya partisipasi, energi dan modal sosial masyarakat. Upaya pemberdayaan perlu dilakukan melalui kelembagaan yang dekat dengan masyarakat dan dapat menggerakan masyarakat; Keempat, distribusi pembangunan yang belum merata. Disinyalir penyebabnya adalah distribusi kelembagaan dan satuan wilayah kerja pemerintah kota yang juga belum merata, sehingga memerlukan tindakan pemerataan kelembagaan dan satuan wilayah kerja di seluruh wilayah kota dan dapat menjangkau sudut-sudut kota yang didiami penduduk; Kelima, lambannya gerak pembangunan ekonomi dan pengelolaan potensi daerah; semakin dinamisnya laju dan gerakan demokrasi; tingginya tingkat kerawanan sosial dan tindak kriminal; serta tingginya tingkat kemiskinan.

Terkait realitas yang terjadi di Kota Bandar Lampung, Pemerintah Kota Bandar Lampung mendefinisikan fenomena dan persoalan yang terjadi selama ini kedalam rumusan masalah (agenda) bahwasanya: "Basis pencapaian sasaran kesejahteraan dan pelayanan publik yang hendak dicapai dalam otonomi daerah berada di wilayah desa dan kelurahan. Dengan demikian seluruh program dan kebijakan pemerintah dan pembangunan harus diarahkan pada lingkungan wilayah desa dan kelurahan. Sebaliknya dinamika pemerintahan wilayah, terutama pemerintahan kelurahan akan sangat menentukan kelancaran pemerintahan dan pembangunan daerah. Dengan kata lain, kondusif atau tidaknya jajaran pemerintahan kelurahan akan berpengaruh terhadap kondusivitas kabupaten/kota” (Dokumen Laporan Studi Kelayakan, 2011).

Dari data-data di atas, memberikan gambaran penting tentang pendefinisian masalah sebagai agenda dan penyebab masalah untuk menentukan langkah dan strategi yang perlu diambil sebagai cerminan wujud strategi tindakan, yaitu : Pertama, sinyalemen terkait pendefinisian masalah sebagai agenda pemerintah terfokus pada peningkatan kesejahteraan dan pelayanan publik yang perlu dimulai dari wilayah desa dan kelurahan, karena merupakan amanah dan sebagai tolak-ukur keberhasilan otonomi daerah. Kedua, adanya penekanan program, kebijakan dan pembangunan perlu difokuskan pada lingkup wilayah kelurahan; dan sekaligus pada level kelurahan menjadi akar penyebab masalahnya. Artinya kelurahan sebagai home-base program, kebijakan pemerintah dan pembangunan; serta disamping itu penyelenggaraan pemerintahan pada lingkup kelurahan adalah garda depan yang bersentuhan langsung dengan masyarakat yang akan menentukan kondusivitas penyelenggaraan pemerintah kabupaten/kota. Tampaknya kedua hal inilah yang menjadi point penting argumentasi Pemerintah Kota Bandar Lampung menetapkan kebijakan pemekaran kecamatan dan kelurahan

Jika uraian diatas ditransformasikan ke dalam dimensi rasionalitas kebijakan, maka nampaknya didapati rasionalitasnya, yaitu: Pertama, kesejahteraan dan pelayanan publik merupakan hak dasar warga dan sebagai kewajiban yang melekat dalam kelembagaan dan aparatur publik, tanpa terkecuali mulai dari level nasional sampai pada tataran street level bureaucracy tingkat kelurahan, bahkan RT (Rukun Tetangga). 
Tabel 1. Indeks Integritas Daerah Tahun 2012

\begin{tabular}{clccc}
\hline \multirow{2}{*}{ No Kota } & \multicolumn{3}{c}{ Indeks Integritas } \\
\cline { 3 - 5 } & & Pengalaman & Potensi & Total Daerah \\
\hline 1 & Bekasi & 6.30 & 5.35 & 5.98 \\
2 & Medan & 6.78 & 4.36 & 5.98 \\
3 & Jayapura & 6.64 & 4.63 & 5.97 \\
4 & Cirebon & 6.22 & 5.47 & 5.97 \\
5 & Bima & 7.10 & 3.48 & 5.90 \\
6 & Ternate & 6.15 & 5.17 & 5.83 \\
7 & Palu & 6.22 & 4.81 & 5.75 \\
8 & Kendari & 6.06 & 5.09 & 5.73 \\
9 & Bandung & 6.02 & 4.97 & 5.67 \\
10 & Serang & 5.93 & 5.13 & 5.67 \\
11 & Bengkulu & 6.08 & 4.80 & 5.66 \\
12 & Semarang & 5.82 & 5.34 & 5.66 \\
13 & Jember & 6.32 & 4.31 & 5.65 \\
14 & Metro & 6.22 & 3.49 & 5.31 \\
$\mathbf{1 5}$ & Bandar Lampung & $\mathbf{5 . 9 2}$ & $\mathbf{3 . 7 3}$ & $\mathbf{5 . 1 9}$ \\
16 & Depok & 5.32 & 4.74 & 5.13 \\
\hline
\end{tabular}

Sumber : Laporan hasil survey dan kajian Komisi Pemberantasan Korupsi (KPK) dalam Tresiana (2013:49)

Tabel 2. Masalah Utama di Kota Bandar Lampung

\begin{tabular}{|c|c|c|}
\hline No. & Masalah Utama & Keterangan \\
\hline 1 & $\begin{array}{l}\text { Masih tingginya angka } \\
\text { kemiskinan masyarakat }\end{array}$ & $\begin{array}{l}\text { Kota Bandar Lampung dalam Angka dalam BPS (2012) } \\
\text { mencatat “jumlah penduduk miskin di kota ini adalah 276.474 } \\
\text { jiwa }(31,4 \%)\end{array}$ \\
\hline 2 & $\begin{array}{l}\text { B uruknya kualitas layanan } \\
\text { publik dan masih rendahnya } \\
\text { kinerja aparatur publik serta } \\
\text { masih tingginya angka } \\
\text { korupsi }\end{array}$ & $\begin{array}{l}\text { KPK (2012) mencatat, indeks integritas Kota Bandar Lampung } \\
\text { untuk pelayanan SIUP 4,83, layanan IMB 4,79, dan layanan } \\
\text { KTP 5,94; sehingga total indeks integritas 5,19. Bukti lain } \\
\text { kasus dibuangnya kakek pasien RSUD Cokrodipo, } \\
\text { ditelantarkan di Gubuk pinggir jalan raya hingga meninggal; } \\
\text { banyaknya aparatur publik di SKPD yang jerjerat kasus } \\
\text { korupsi }\end{array}$ \\
\hline
\end{tabular}

Artinya suatu keniscayaan dan tak terbantahkan bahwa eksistensi negara, provinsi, kabupaten/kota, dan desa/kelurahan secara hakiki memang untuk mewujudkan kesejahteraan dan memberikan layanan publik dalam makna makro. Kedua, wilayah dan penduduk dari negara, provinsi dan kabupaten/kota sesungguhnya merupakan wilayah dan penduduk kelurahan. Dengan kata lain, secara faktual kelurahanlah yang mempunyai wilayah dan penduduk, sehingga wajar dan tidak aneh kalau kelurahan menjadi home-base program, kebijakan pemerintah dan pembangunan. Ketiga, pemerintahan diatas level kelurahan mempunyai struktur dan aparatur kelembagaan tersendiri, tetapi karena wilayah dan penduduk riil ada pada kelurahan, maka sangat wajar dan rasional jika penyelenggaraan pemerintahan kelurahan menjadi penentu kondusivitas penyelenggaraan pemerintah kabupaten/kota.

Namun jika ditelaah, dengan menggunakan kerangka Dunn (2000) dalam idealisasi perumusan kebijakan, maka kebijakan pemekaran kecamatan/kelurahan haruslah menggambarkan 2 tahapan penting, yakni : Pertama, identifikasi masalah material yang ditunjukkan: (a) kegiatan pendataan sejumlah fenomena dan persoalan faktual utama yang sedang dihadapi. Kedua, dimensi formal yang meliputi: (a) penentuan agenda kebijakan melalui serangkaian kegiatan pemetaan semua hal yang menjadi penyebab utama masalah; dan (b) identifikasi opsi, penentuan dan penetapan strategi kebijakan sebagai solusi masalah. Dengan demikian, ukuran sukses atau tidaknya outcome kebijakan, akan sangat tergantung dari akurasi deteksi aktor kebijakan terhadap masalah material dan kesesuaiannya dengan akar penyebab utama; identifikasi dan penetapan opsi serta strategi kebijakan sebagai solusi nyata permasalahan.

Terkait dengan identifikasi isu penting yang dikemukakan oleh Pemerintah Kota Bandar Lampung, tampaknya belum menyentuh persoalan substantif tentang penyebab masalah, khususnya mengenai persoalan kemiskinan; buruknya kualitas pelayanan; 
Tabel 3. Dasar Pemilihan Alternatif dalam Penetapan Kebijakan Pemekaran

\begin{tabular}{|c|c|c|}
\hline No. & Dimensi Pertimbangan & Hasil/Outcome \\
\hline 1 & $\begin{array}{l}\text { Kelayakan tehnis (efektivitas, } \\
\text { kecukupan) }\end{array}$ & $\begin{array}{l}\text { Perumusan kebijakan yang cepat ( } 3 \text { bulan), tidak ada masyarakat } \\
\text { yang menolak pemekaran ini karena menurut mereka pemekaran } \\
\text { ini tidak berpengaruh terhadap kesejahteraan mereka, namun } \\
\text { mereka hanya menkhawatirkan perihal perubahan identitas } \\
\text { alamat mereka yang justru menambah beban bagi masyarakat } \\
\text { dalam hal kepengurusan surat, dan terjadi penolakan nama } \\
\text { kecamatan/kelurahan }\end{array}$ \\
\hline 2 & $\begin{array}{l}\text { Kelayakan Ekonomi dan } \\
\text { Finansial }\end{array}$ & $\begin{array}{l}\text { Diperlukan dana yang tidak sedikit, dengan asumsi } 1 \\
\text { kelurahan/kecamatan memerlukan dana sekitar } 700 \text { juta yang } \\
\text { cukup membebankan anggaran daerah }\end{array}$ \\
\hline 3 & Kelayakan Politik & $\begin{array}{l}\text { Ada konsensus politik antarpemangku kepentingan, uji publik } \\
\text { tidak dilakukan, alternatif kebijakan pemekaran berfokus pada } \\
\text { dukungan dari Undang-Undang Nomor } 32 \text { Tahun } 2004 \text { sehingga } \\
\text { hal ini dijadikan sebagai alasan formal kebijakan tersebut, } \\
\text { masyarakat bersikap pasif terhadap kebijakan ini, didominasi } \\
\text { oleh kepentingan elite politik. }\end{array}$ \\
\hline 4 & Segi Administratif & Sarana prasarana, staf/sumberdaya belum memadai \\
\hline
\end{tabular}

rendahnya kompetensi aparatur publik dan korupsi yang sesungguhnya terjadi.

Duadji (2012:72) menyatakan bahwa akurasi pendefinisian masalah, ketepatan deteksi akar penyebab dan kesesuaian strategi sebagai cara atau metode tindakan yang diambil pemerintah untuk memutus mata-rantai atau paling tidak mampu mengeliminir penyebab terjadinya masalah menjadi penentu (determinan) sukses atau gagalnya tindakan (kebijakan) yang diambil. Jika tidak, maka Dunn (2000) menyatakan akan terjadi kesalahan tipe 2, artinya tidak ada keterkaitan logis antara masalah, penyebab dan kebijakan yang diambil pemerintah sehingga menyebabkan kebijakan irasional.

Proses perumusan kebijakan, diawali dan langsung diakhiri dengan penetapan satu opsi strategi yaitu pemekaran kecamatan dan kelurahan. Opsiopsi yang lain dan perhitungan nilai kemanfaatannya tidak dilakukan. Analisis dan pembobotan hanya untuk satu opsi pemekaran, tidak ada proses komparasi dan analisis tentang sejumlah opsi yang dapat dijalankan pemerintah.

Seharusnya, tindakan atau strategi yang diambil Kota Bandar Lampung, bukanlah kebijakan pemekaran, namun diarahkan kepada pengembangan kapasitas atau kemampuan sumberdaya aparatur, ilmu pengetahuan, teknologi, organisasi, kelembagaan dan sumber daya lain pada Kota Bandar Lampung. Tujuan mendasar pengembangan kapasitas adalah, peningkatan kemampuan untuk mengevaluasi dan menjawab pertanyaan-pertanyaan penting yang berkaitan dengan pilihan kebijakan dan cara pelaksanaan diantara pilihan pembangunan, berdasarkan pemahaman tentang potensi lingkungan, batas-batas dan kebutuhan yang dirasakan oleh masyarakat kota. Dengan kata lain, peningkatan kapasitas, merupakan strategi yang ditujukan untuk meningkatkan kinerja pelayanan melalui pengembangan sumber daya manusia, penguatan organisasi, reformasi kelembagaan, variasi program/kebijakan yang secara langsung mencapai subyek sasarannya dan pembentukan dan penguatan jaringan sosial (social networking).

Rasionalitas dalam Penetapan Kebijakan Pemekaran Kecamatan/Kelurahan

Kerangka rasionalitas dalam kebijakan pemekaran diawali dengan pendifinisian kebijakan dari persoalan riil masyarakat, mengemukakan beberapa pilihan alternatif dan diakhiri dengan sebuah pemilihan alternative dari sejumlah alternative yang ada, sehingga pilihan yang rasional (rational choice) mencakup pemilihan alternative terbaik, bagi tercapainya tujuan dan nilai yang fundamental dan tepat guna untuk mencapai hasil akhir (outcome) yang diinginkan. Dalam konteks pemekaran kecamatan/kelurahan, diawal reformasi sampai dengan tahun 2000, Kota Bandar Lampung mempunyai 9 kecamatan dan 84 kelurahan. Antara tahun 2001-2011 terdiri dari 13 kecamatan dan 98 kelurahan; dan tahun 2011 akhir sampai dengan sekarang memiliki 20 kecamatan dan 126 kelurahan. Artinya pada priode pemekaran pertama (tahun 2001) ada penambahan 4 kecamatan dan 14 kelurahan baru; sementara pada priode pemekaran kedua (tahun 2011) ada penambahan 7 kecamatan dan 28 kelurahan. Dengan demikian selama kurun waktu ke-2 priode pemekaran, ada 11 kecamatan baru dan 42 kelurahan baru, seperti terlihat pada Tabel 4.

Kebijakan pemekaran kecamatan dan kelurahan di Kota Bandar Lampung merupakan tindakan sengaja dan terencana yang dilakukan oleh Pemerintah Kota Bandar Lampung, tidak seperti perbuatan emergensi, seperti dalam kasus 
Tabel 4. Pertumbuhan Kecamatan dan Kelurahan dalam Priodesasi Pemekaran Wilayah Kecamatan dan Kelurahan di Kota Bandar Lampung

\begin{tabular}{|c|c|c|c|c|}
\hline \multirow[b]{2}{*}{ Tahun } & \multicolumn{4}{|c|}{ Jumlah } \\
\hline & Kecamatan & $\begin{array}{c}\text { Pertambahan } \\
\text { kecamatan karena } \\
\text { pemekaran }\end{array}$ & Kelurahan & $\begin{array}{c}\text { Pertambahan } \\
\text { kelurahan } \\
\text { karena } \\
\text { pemekaran } \\
\end{array}$ \\
\hline $1998-2000$ & 9 & & 84 & \\
\hline 2001-2011 & 13 & 4 & 98 & 14 \\
\hline 2011-Sekarang & 20 & 7 & 126 & 28 \\
\hline \multicolumn{2}{|c|}{ Total Pertambahan } & 11 & & 42 \\
\hline
\end{tabular}

Sumber: Diolah dari Dokumen Laporan Akhir Studi Kelayanan Pemekaran Kecamatan dan Kelurahan

penanganan bencana yang memerlukan tindakan tanggap darurat. Pemekaran kecamatan dan kelurahan itu merupakan produk pikiran logis berdasarkan pilihan (preferensi) rasionalitas tertentu.

Beberapa hasil wawancara berkaitan dengan rasionalitas yang digunakan aktor dalam kebijakan pemekaran kecamatan/Kelurahan di Kota Bandar Lampung tergambar sebagai berikut:

Kepala Sub Bagian Tata Pemerintahan Umum Setda Kota Bandar Lampung, kebijakan pemekaran wilayah kecamatan dan kelurahan mempunyai landasan formal, yaitu Undang-Undang tentang Pemerintahan Daerah atau lebih sering disebut dengan UU Otonomi Daerah yang menuntut kemajuan dan kemandirian daerah, seperti tergambar dalam kutipan wawancara berikut ini: "Pemekaran wilayah kecamatan/kelurahan ini dilakukan sejalan dengan diberlakukannya undang-undang otonomi, memberikan kewenangan penyelenggaraan pemerintah daerah yang lebih luas, nyata dan bertanggung jawab. Adanya perimbangan tugas fungsi dan peran antara pemerintah pusat dan pemerintah daerah tersebut menyebabkan masingmasing daerah harus memiliki penghasilan yang cukup, daerah harus memiliki sumber pembiayaan yang memadai untuk memikul tanggung jawab penyelenggaraan pemerintahan daerah. Dengan demikian diharapkan masing-masing daerah akan dapat lebih maju, mandiri, sejahtera dan kompetitif di dalam pelaksanaan pemerintahan maupun pembangunan daerahnya masing-masing "(Wawancara dengan Bapak Ahmad Efendi, S.IP., M,IP, tanggal 7 Oktober 2013).

Sementara, pandangan yang dilontarkan salah seorang anggota DPRD Komisi A Kota Bandar, pertimbangan kebijakan pemekaran kecamatan dan kelurahan adalah sebagai upaya merespon inisiatif eksekutif (Walikota) dan pertimbangan pada dimensi jumlah penduduk dan luas wilayah yang memungkinkan untuk dimekarkan, sehingga ekspektasinya akan ada peningkatan pelayanan. Berikut ini kutipan wawancaranya: "Isu pemekaran kelurahan tidak hanya berasal dari walikota melainkan berasal dari masyarakat juga. Pemekaran yang dilakukan di Kota
Bandar Lampung yang semula memilki 98 kelurahan kemudian menjadi 126 kelurahan adalah hal yang perlu dilakukan karena melihat dari jumlah penduduk yang cukup besar dan luas wilayah. Dengan memperhatikan 3 (tiga) aspek yaitu aspek hukum, birokrasi dan sosial, sehingga dapat meningkatakan pelayanan masyarakat agar lebih efektif dan efisien" (Wawancara dengan Bapak Romi Husin, S.H., dan didampingi Bapak Yusuf Efendi, S.E., tanggal 16 Oktober 2013).

Menyikapi kebijakan pemekaran kecamatan dan kelurahan, pemikiran Kasi Pemerintahan Kecamatan Tanjung Karang Barat lebih didasarkan pada built-up area seperti terlihat pada kutipan wawancara berikut: "Pemekaran wilayah biasanya merupakan wujud dari keinginan masyarakat di suatu daerah (dalam dimensi geografis) untuk tumbuh dan berkembang dari segi ekonomi, politik, sosial, budaya dan keamanan. Tingkat perkembangan wilayah dapat dilihat dari rasio luas wilayah terbangun (built-up area) terhadap total luas wilayah. Semakin besar rasionya, maka semakin tinggi tingkat perkembangan wilayahnya. Semakin luas built up areanya dapat diartikan semakin tinggi aktivitas ekonomi masyarakatnya. Kondisi tersebut dapat dilihat dari semakin rapatnya jaringan jalan, semakin meluasnya wilayah perkantoran dan perdagangan, semakin menyebarnya wilayah pemukiman dengan kepadatan penduduk yang tinggi dan tingginya peluang kerja"( Wawancara dengan Bapak Andy Umbara, S.Sos., tanggal 8 Oktober 2013).

Lurah Kelurahan Sukajawa (salah satu kelurahan di Kota Bandar Lampung) mengemukakan luas wilayah dan jumlah penduduk yang tidak merata dalam kelurahan-kelurahan menjadi dasar pemekaran, seperti dalam kutipan berikut ini. "Alasan pemekaran kelurahan dan kecamatan, karena faktor luas wilayah dan jumlah penduduk yang tidak merata dalam kecamatan-kecamatan dan kelurahan-kelurahan di Kota Bandar Lampung. Ada yang over populasi, contoh di Kelurahan Sukajawa Baru, penduduknya terbanyak ke-2 di Kecamatan Tanjungkarang Barat. Pemekaran bertujuan untuk memperpendek rentang kendali pada masyarakat" 
(Wawancara dengan Bapak Gusrizal, S.Ag., tanggal 10 Oktober 2013).

Salah seorang akademisi FISIP Universitas Lampung yang merupakan anggota tim studi kelayakan pemekaran, memberikan tanggapan mengenai pemekaran kecamatan dan kelurahan sebagai kesiapan dan upaya yang perlu dilakukan dalam proses pemekaran itu sendiri, seperti dalam kutipan berikut ini. "Dalam merumuskan kebijakan pemekaran kelurahan tim peneliti Unila telah melakukan identifikasi, verifikasi awal, dan menggali lebih dalam menangani rencana pemekaran kelurahan dan kecamatan di Kota Bandar Lampung melalui pertemuan rapat yang dihadiri 98 lurah, 13 camat, satuan kerja terkait, bagian tata pemerintahan, asisten I, dan Walikota Bandar Lampung. Pada rapat tersebut tim peneliti Unila menyebarkan kuisoner untuk 98 lurah dan 13 camat". (Wawancara dengan Bapak Maulana Mukhlis, S,IP., M,IP. Pada tanggal 12 Oktober 2013)

Berdasarkan kutipan wawancara dengan para informan diatas dan data-data serta informasi lain, maka dapat penulis menganalisis, bahwasanya tindakan yang dilakukan para aktor kebijakan sebagai representasi Pemerintah Kota Bandar Lampung dalam tataran implementatifnya mencerminkan beberapa hal pokok.

Pertama, memaknai penataan ulang kelembagaan publik sebagai pemekaran yang merupakan konsekuensi logis dari adanya UU Nomor 32/2004 tentang Pemerintahan Daerah (otonomi), dan landasan operasional yang termuat dalam PP Nomor 78 Tahun 2007 Tentang Tatacara Pembentukan, Penghapusan, dan Penggabungan Daerah; PP Nomor 72 Tahun 2005 tentang Pembentukan Kelurahan dan PP Nomor 73 tahun 2005 tentang kelurahan. Artinya, pemekaran adalah otoritas legal formal pemerintah yang mempunyai sandaran regulasi atau landasan legal formal (hukum/kebijakan).

Kedua, para aktor lebih fokus pada aspek cara bukan dimensi tujuan, yaitu tindakan pemekarannya, bukan solusi untuk memutus atau mengeliminir penyebab terjadinya masalah utama dalam penyelenggaraan tatanan kelembagaan pemerintah Kota Bandar Lampung seperti tercantum pada beberapa tabel di atas. Akibatnya semua tindakan aktor lebih terpusat pada persoalan proses, teknis dan administratif tentang operasionalisasi strategi pemekaran kecamatan dan kelurahannya, sehingga seolah-olah pemekaran kecamatan dan kelurahan merupakan tujuan, padahal hanya merupakan suatu cara dan tentu masih banyak cara berupa strategi ataupun pilihan lainnya.

Ketiga, persyarat teknis pemekaran kecamatan dan kelurahan diturunkan melalui miksasi PP Nomor 78 Tahun 2007; PP Nomor 72 Tahun 2005 dan PP Nomor 73 tahun 2005. Dengan demikian terjadi kontradiksi standar (persyaratan). Perlu diingat PP Nomor 78 Tahun 2007 adalah tentang Tatacara Pembentukan, Penghapusan, dan Penggabungan Daerah. Kata daerah merujuk pada daerah otonom, yaitu provinsi, kabupaten/kota dan desa karena pertimbangan asal-usulnya. Sementara kecamatan dan kelurahan bukan atau tidak dapat dikatakan sebagai daerah otonom, melainkan wilayah administrative, perpanjangan SKPD yang tidak memiliki otoritas khusus. Peraturan Pemerintah (PP) Nomor 72 Tahun 2005 tentang Pembentukan Kelurahan dan PP Nomor 73 tahun 2005 tentang kelurahan dimana kata pembentukan bukanlah sinonim dari pemekaran. Kedua PP tentang kelurahan tersebut mengatur tata cara pembentukan (dapat berupa tindakan pemekaran atau penggabungan) baik pada kecamatan/kelurahan yang berdekatan; didalam wilayah induk kecamatan/kelurahan; atau antara bagian kecamatan/kelurahan.

Disamping itu ada syarat substansial lainnya, yaitu kesiapan, kemandirian (sumber finansial, sumberdaya aparatur), perkembangan perekonomian masyarakat dan permintaan masyarakat. Berkenaan dengan uraian ini, maka validitas analisis tim think tank tentang pembobotan syarat kelayakan pemekaran perlu dipertanyakan. Terkait syarat substansial dapat dikatakan tidak terpenuhi terlihat pada Surat Walikota Nomor: 130/2180/I.01/2011, tanggal 12 Desember 2011 tentang persiapan dan rencana Pemerintah Kota Bandar Lampung. Menyambut Kehadiran Kelurahan dan Kecamatan Baru dengan priode dan agenda yang wajib dilakukan SKPD. Pada tahun 2012 melalui dana APBD dengan agenda: (1) Badan Pengelolaan Keuangan dan Aset Daerah ditugasi untuk menyiapkan dana operasional kecamatan dan kelurahan hasil pemekaran; (2) Bagian Perlengkapan ditugasi untuk menyiapkan pengadaan saranaprasarana (falitas) kantor kecamatan dan kelurahan hasil pemekaran. Pada tahun 2013 melalui dana APBD tahun 2013 dengan agenda: Bagian Pemerintahan ditugasi membuat peta dan patok tanda batas semua kecamatan dan kelurahan induk dan hasil pemekaran. Pada tahun 2014 melalui APBD tahun 2014 dengan agenda: (1) Dinas Pekerjaan Umum ditugasi membangun gedung kantor dan fasilitas terkait bagi kecamatan dan kelurahan hasil pemekaran; dan BKD ditugasi untuk membuat perencanaan dan melakukan job analysis untuk pengisian struktur (jabatan) sesuai eselonering kecamatan dan kelurahan hasil pemekaran yang terdiri dari eselon IIIa berjumlah 7 personel; eselon IIIb sebanyak 7 personil; eselon Iva sejumlah 62 personel; eselon IVb sejumlah 129 personel; serta sejumlah staf sesuai kebutuhan masing-masing. Uraian ini jelas mencerminkan adanya beban baru, bukan kemandirian wilayah administratif baru (kecamatan dan kelurahan) hasil pemekaran.

Keempat, pemekaran lebih merupakan political intrest aktor kebijakan ketimbang upaya solutif atas penyebab masalah dan patologi 
pemerintah daerah yang selama ini mengemuka di Kota Bandar Lampung. Politis disini dalam makna motif rejim (kolaborasi di lembaga eksekutif dan legislatif) untuk menduplikasi panca-indranya melalui jalur birokrasi (camat, lurah dan aparaturnya) yang diberikan reward jabatan dan fasilitas yang melekat lainnya diawal sehingga menjadi client setia elit politik. Pada konteks ini transaksi dan investasi political capital terjadi dan client birokrasi ini suatu saat akan dimanfaatkan pada proses politik pemilihan selected law makers and executives dalam pesta demokrasi berikutnya.

Dalam konteks teori rasionalitas, Simon dalam Parsons, (2006:281) menyatakan Kendatipun aktor kebijakan sangat kompleks dan beragam, tetapi dapat diidentifikasikan secara kolektif kedalam aktor utamanya yang merupakan elit (sosial, politik dan ekonomi). Proses politik merupakan area dan arena masing-masing pihak untuk berinteraksi, melakukan kalkulasi, membentuk jaringan (network), berinvestasi dan berkolaborasi. Oleh karenanya teori ini memandang kebijakan bersifat transaksional, yaitu pertukaran kepentingan diantara para elit, bukanlah sebagai respon sistem (legislatif dan eksekutif) untuk mengatasi masalah faktual yang berkaitan dengan penyelenggaraan sistem”. Kemudian, kendati Cyert \& March dalam Frederickson (2012:68) menyatakan bahwa: "Political democracy depends not only on economic and social contributions but also on the design of political institution. The importance of the design of institutions on their behavior and on their political outcomes", tetapi pada dasarnya kesimpulan yang dikemukakan senada dengan penjelasan kedua teori diatas.

Menurut Cyert \& March dalam Frederickson (2012), bahwasanya dalam konteks perumusan dan penetapan kebijakan, perilaku aktor tampaknya mengikuti alur (logika) garbage can atau tong sampah, tidak mengikuti proses, siklus dan tahapan kebijakan yang semestinya. Aktor kebijakan memulai langkah awal dan sekaligus menjadi step akhir proses, yaitu langsung tertuju pada satu opsi sebagai satu-satunya strategi atau kebijakan yang akan diambil dan kemudian langsung ditetapkan. Proses-proses yang menyertai berikutnya hanyalah merupakan upaya untuk mencarikan penguat dan pembenar atau justifikasi opsi (kebijakan) yang telah ditetapkan sebelumnya. Kebijakan merupakan hasil respon struktur terhadap kepentingannya”.

Penjelasan diatas terverifikasi dari data dan informasi tentang hal yang melatarbelakangi kebijakan pemekaran kecamatan dan kelurahan di Kota Bandar Lampung seperti uraian Tresiana (2013) bahwasanya terkait masih banyaknya keluhan tentang Daptar Pemilih Sementara, Daftar Pemilih Tetap dan pembagian Daerah Pemilihan pada penyelenggaraan pemilu tahun 2009, maka Menteri Dalam Negeri mengeluarkan surat kepada seluruh kepala daerah untuk menyusun dan melakukan penyempurnaan Dapil dan data-data pendukung lainnya sehingga kualitas penyelenggaraan pemilu tahun 2014 akan menjadi lebih berkualitas. KPU juga berkoordinasi dengan Pemprov Lampung dan Pemkab/Pemkot se-Provinsi Lampung untuk menindaklanjuti surat Mendagri tersebut. Bagi Lampung, hal ini menjadi sangat urgen karena selain pemilu legislatif, presiden/wakil presiden juga akan dilaksanakan pemilihan Gubernur/Wakil Gubernur pada tahun yang sama. Terkait hal ini, Pemerintah Kota Bandar Lampung melakukan penyempurnaan melalui pemekaran kecamatan dan kelurahan yang sekaligus merupakan upaya penataan kelembagaan Pemerintah Kota Bandar Lampung.

Jika demikian, maka pemekaran kecamatan dan kelurahan lebih merupakan persoalan struktur (kebutuhan dan kepentingan Pemerintah Kota Bandar Lampung) dan masyarakat belum memandang hal ini sebagai kebutuhan. Alasan tentang adanya rentang kendali yang terlalu jauh seperti yang dikemukan didalam hasil studi kelayakan pemekaran kurang tepat dan terkesan dibuat-buat. Istilah span of control merupakan konsep hubungan hirarkisial yang digagas oleh Urwick dan Gulick (dalam Safarudin,2009). Span of control merupakan prinsip manajemen senada dengan prinsip kesatuan komando, prinsip rentang kendali menghendaki sebaiknya seorang atasan memiliki jumlah bawahan yang tidak terlalu banyak, sehingga kotrol terhadap bawahan bisa berjalan efektif. Struktur organisasi didesain sedemikian rupa sehingga hubungan hirarkis tidak terlalu panjang, rentang kendali semakin sempit dan lebih mudah untuk mengendalikan aktivitas organisasi. Dengan demikian, maka sesungguhnya prinsip desain organisasi publik (pemerintah) haruslah rasional. Artinya desain organisasi merupakan cara yang ditempuh dalam menyusun organisasi pemerintah sesuai prinsip dan pertimbangan rasional, yaitu berkenaan dengan persoalan substansial yang fungsional apa yang sedang dihadapi, dimana tempatnya, bagaimana prosesnya, apa tujuannya dan dampak positif apa yang akan dinikmati masyarakat. Jadi makna desain tidak dapat diidentikan dengan pemekaran.

\section{KESIMPULAN}

Proses pembuatan dan penetapan kebijakan pemekaran kecamatan/kelurahan di Kota Bandar Lampung belum merupakan upaya solutif untuk mengatasi masalah-masalah substantive masyarakat. Persoalan kemiskinan dan buruknya pelayanan publik, dipecahkan dengan penetapan satu opsi strategi yaitu pemekaran kecamatan dan kelurahan. Opsi-opsi yang lain dan perhitungan nilai kemanfaatannya tidak dilakukan. Analisis dan pembobotan hanya untuk satu opsi pemekaran, tidak ada proses komparasi dan analisis tentang sejumlah 
opsi yang dapat dijalankan pemerintah. Seharusnya, tindakan solutif bukanlah kebijakan pemekaran, namun diarahkan kepada pengembangan kapasitas atau kemampuan sumberdaya aparatur, ilmu pengetahuan, teknologi, organisasi, kelembagaan dan sumber daya lain pada Kota Bandar Lampung.

Rasionalitas yang digunakan aktor dalam penetapan kebijakan pemekaran kecamatan/kelurahan di Kota Bandar Lampung mengikuti alur model garbage can atau tong sampah. Penetapan kebijakan tidak mengikuti proses, siklus dan tahapan kebijakan yang semestinya. Aktor kebijakan memulai langkah awal dan sekaligus menjadi tahap akhir proses, yaitu langsung tertuju pada satu opsi sebagai satu-satunya strategi atau kebijakan yang akan diambil dan kemudian langsung ditetapkan. Proses-proses yang menyertai berikutnya hanyalah merupakan upaya untuk mencarikan penguat dan pembenar atau justifikasi opsi (kebijakan) yang telah ditetapkan sebelumnya. Kebijakan pemekaran lebih merupakan hasil respon struktur terhadap kepentingannya elit (politik), bersifat transaksional, yaitu pertukaran kepentingan diantara para elit, bukanlah sebagai respon sistem (legislatif dan eksekutif) untuk mengatasi masalah faktual yang berkaitan dengan kesejahteraan masyarakat.

Karenanya sebagai catatan penutup, sebagai saran adalah Kementrian Dalam Negeri, perlu dilakukan kajian ulang secara mendalam tentang syarat dan sandaran regulasi penataan keorganisasian daerah otonom, dan wilayah administratif sebagai upaya mensejahterakan rakyat bukan malah menjadi beban anggaran daerah, yang akan mengurangi program publik, jika memungkinkan perlu dilakukan moratorium pemekaran wilayah. 


\section{Daftar Pustaka}

Abdul Wahab, Solichin. 2008. Analisis Kebijakan Publik. Malang. Universitas Muhamadiyah Press.

Cresswell, J.W. 2002. Desain Penelitian: Pendekatan Kualitatif dan Kuantitatif. Jakarta: KIK Press

Dunn, William.2000. Pengantar Analisis Kebijakan Publik, Edisi Kedua. Gadjah Mada University Press. Yogyakarta

Frederickson, H. George. 2012. The Public Administration Theory Primer. Philadelphia (USA): Westview Press.

Lindblom,Charles E.1986. Proses Penetapan Kebijakan Edisi Kedua. Jakarta: Erlangga.

Long, N. \& Long, A. (eds.). 1992. Battlefield of Knowledge: The Interlocking of Theory and Practice in Social Research and Development. London: Routledge.

Parsons,Wayne.2006. Public Policy: Pengantar Teori dan Praktek Analisis Kebijakan. Jakarta. Kencana.

Subarsono, AG.2005. Analisis Kebijakan Publik: Konsep, Teori dan Aplikasi. Pustaka Pelajar. Yogyakarta

\section{Laporan Penelitian dan Dokumen-Dokumen}

Duadji, Noverman. 2013. "Partisipasi Publik dalam Pengambilan Keputusan APBD Propinsi Lampung”, dalam Jurnal Bina Praja: Jurnal Penelitian dan Pengembangan Bidang Pemerintahan Dalam Negeri Vol. 5 No. 3 September 2013. H.65. Jakarta: Badan Penelitian dan Pengembangan Kementerian Dalam Negeri.

Duadji, Noverman. 2012. "Good Governance dalam Pemerintah Daerah”, dalam Jurnal Mimbar: Jurnal Sosial dan Pembangunan Vol. 28 No. 2 Desember 2012. H.201-209. Bandung: Universitas Islam Bandung.

Fitri. 2012. Formulasi Kebijakan Pemekaran Kelurahan Sukajawa Kota Bandar Lampung. Skripsi. Badar Lampung. Universitas Lampung. (Tidak diterbitkan)

Evaluasi Pemekaran Daerah Otonom dan Adminsitratif Tahun 2010. Diakses Tanggal 05 Agustus 2014. www.kemendagri.com

Prasetyo, Budi,. 2012. “Orientasi Aktor dalam Perumusan Kebijakan Publik” dalam Jurnal Masyarakat, Kebudayaan dan Politik, Vol 21, Nomor 2:115-130. Surabaya. Departemen Sosiologi, Fisip Unair Press

Pemerintah Kota Bandar Lampung-Tim Peneliti Magister Hukum Fakultas Hukum Universitas Lampung. 2011. Dokumen Laporan Akhir: Studi Kelayakan Pemekaran Kelurahan dan Kecamatan di Kota Bandar Lampung. Bandar Lampung. Tidak Diterbitkan

Peraturan Pemerintah Nomor 72 Tahun 2005 tentang Pembentukan Kelurahan.

Peraturan Pemerintah Nomor 73 tahun 2005 tentang kelurahan.
Peraturan Pemerintah Nomor 78 Tahun 2007 tentang Tatacara Pembentukan, Penghapusan, dan Penggabungan Daerah.

Syafarudin. 2009. "Pemetaan Makna Politik Pemekaran Daerah di Indonesia”, dalam Prosiding Lembaga Penelitian Universitas Lampung. Bandar Lampung

Surat Walikota Bandar Lampung No.130/2180/I.01/2011 Tanggal 12 Desember 2011 tentang Kesiapan Pemekaran/Penataan Kecamatan dan Kelurahan

Tresiana, Novita. 2013. “Pemekaran Kecamatan dan Kelurahan: Diskursus perspektif Garbage Can Theory tentang Cara atau Tujuan dalam Formulasi Kebijakan Pemekaran Kecamatan di Kota Bandar Lampung”. Laporan Hasil Penelitian Mandiri. FISIP Universitas Lampung: Tidak Diterbitkan.

Undang-Undang Nomor 32 Tahun 2004 tentang Pemerintahan Daerah

Weick, Karl E and Quinn, Robert E,. 1999. "Organizational change and development" dalam Annual Review of Psychology. Volume 50. p.361. Ann Arbor, Michigan 48109: University of Michigan Business School, University of Michigan. 
